\title{
The use of probiotics in animal feeding for safe production and as potential alternatives to antibiotics
}

\author{
Mbarga M. J. Arsène ${ }^{1,2}$ (D) Anyutoulou K. L. Davares ${ }^{2}$ (D) Smolyakova L. Andreevna1(i), Ermolaev A. Vladimirovich ${ }^{1(\mathbb{D})}$ \\ Bassa Z. Carime ${ }^{2}$ (D), Razan Marouf ${ }^{1}$ (i) and Ibrahim Khelifi ${ }^{1}$ (i)
}

1. Department of microbiology and virology, Institute of Medicine, RUDN University, Moscow, Russia; 2. Department of Food Sciences and Nutrition, National School of Agro-industrial Sciences, University of Ngaoundere, Cameroon;

3. Department of Process Engineering, National School of Agro-industrial Sciences, University of Ngaoundere, Cameroon. Corresponding author: Mbarga M. J. Arsène, e-mail: josepharsenembarga@yahoo.fr

Co-authors: AKLD: davarsene@yahoo.com, SLA: larisa.biology@mail.ru, EAV: ermolaev2007@inbox.ru, BZC: zachariecarime@gmail.com, RM: razanma3rouf@gmail.com, IK: khelifiiibrahim@gmail.com Received: 14-10-2020, Accepted: 28-12-2020, Published online: 03-02-2021

doi: www.doi.org/10.14202/vetworld.2021.319-328 How to cite this article: Arsène MMJ, Davares AKL, Andreevna SL, Vladimirovich EA, Carime BZ, Marouf R, Khelifi I (2021) The use of probiotics in animal feeding for safe production and as potential alternatives to antibiotics, Veterinary World, 14(2): 319-328.

\begin{abstract}
Although the production of safe food for human consumption is the primary purpose for animal rearing, the environment and well-being of the animals must also be taken into consideration. Based on microbiological point of view, the production of healthy food from animals involves considering foodborne pathogens, on the one hand and on the other hand, the methods used to fight against germs during breeding. The conventional method to control or prevent bacterial infections in farming is the use antibiotics. However, the banning of these compounds as growth promoters caused many changes in animal breeding and their use has since been limited to the treatment and prevention of bacterial infections. In this function, their importance no longer needs to be demonstrated, but unfortunately, their excessive and abusive use have led to a double problem which can have harmful consequences on consumer health: Resistance to antibiotics and the presence of antibiotic residues in food. The use of probiotics appears to be a suitable alternative to overcome these problems because of their ability to modulate the immune system and intestinal microflora, and further considering their antagonistic role against certain pathogenic bacteria and their ability to play the role of growth factor (sometimes associated with prebiotics) when used as feed additives. This review aims to highlight some of the negative effects of the use of antibiotics in animal rearing as well as emphasize the current knowledge on the use of probiotics as a feed additive, their influence on animal production and their potential utility as an alternative to conventional antibiotics, particularly in poultry, pig, and fish farming.
\end{abstract}

Keywords: animal nutrition, antibiotic resistance, feed additive, fish farming, pig, poultry, probiotic, safe production.

\section{Introduction}

In most developed countries, the amount of protein consumed is on average above $1.4 \mathrm{~g} / \mathrm{kg}$ daily and animal proteins represent $65-70 \%$ of the total protein intake [1]. To meet the growing demand, livestock industries of all classes have resorted to various techniques to increase their output [2]. In addition to setting up intensive and semi-intensive farming system, these new techniques are particularly intended to accelerate the growth of animals, protect them against diseases, improve feed conversion efficiency, and optimize reproduction by limiting the mortality rates during birth [3].

Antibiotics have long been used in animal husbandry as growth promoters, on the one hand and on the other hand, as treatment for bacterial diseases [4]. The prohibition of antibiotics as growth promoters and the harmful effects resulting from its abusive use (resistance to antibiotics and presence of antibiotic residues in food and the environment) increasingly

Copyright: Arsène, et al. Open Access. This article is distributed under the terms of the Creative Commons Attribution 4.0 International License (http://creativecommons.org/licenses/by/4.0/), which permits unrestricted use, distribution, and reproduction in any medium, provided you give appropriate credit to the original author(s) and the source, provide a link to the Creative Commons license, and indicate if changes were made. The Creative Commons Public Domain Dedication waiver (http://creativecommons.org/ publicdomain/zero/1.0/) applies to the data made available in this article, unless otherwise stated. force breeders to look for other more eco-efficient methods [5]. From the beginning of $21^{\text {st }}$ century, several studies have been carried out presenting probiotics as being able to play a preponderant role in breeding, either as a simple additive with beneficial effects on growth or as a potential alternative to conventional antibiotics [6-8]. Numerous recent studies have shown that supplementing probiotics in animal feed positively alter the gut microbiota, reduce pathogen shedding and disease symptoms, increases gut immunity, and improve disease resistance and health [9-15]. In addition, probiotics have their antagonistic effect and their ability to regulate the gut microflora can significantly reduce foodborne pathogens such as Campylobacter, Clostridium perfringens, Escherichia coli, Listeria monocytogenes, Salmonella, and Staphylococcus aureus [16-19].

This review, therefore, serves to highlight the applications of probiotics in animal breeding (pig, poultry, and fish) as well as their potential utility as an alternative to conventional antibiotics.

\section{Harmful Consequences of the Use of Antibiotics in Animal Breeding}

\section{Resistance to antibiotics}

Antibiotic resistance is defined as the ability of bacteria to resist the inhibitory or destructive activity 
of an antibiotic to which it was not resistant [20]. This resistance, in particular, is associated with excessive or sometimes uncontrolled use of antibiotics in breeding and the mechanisms of transmission of resistance between bacteria. This phenomenon concerns both animals and humans and the transmission of resistance between them is possible because they share the same ecosystem (Figure-1). Indeed, resistant bacteria, resistance genes (especially associated with mobile genetic elements), and antibiotic residues can circulate between the different niches of the ecosystem [5]. By direct or indirect contact (food, water, and environment) between animals and human, bacteria can, therefore, pass from animals to human, and on the contrary. This applies both to commensal bacteria, which are often considered as reservoirs of resistance due to their widespread presence and long-term antibiotic exposure in the gut of food animals (use of antimicrobial growth promoters at subtherapeutic levels), and also to pathogenic bacteria [5]. Furthermore, recent studies have shown that multi-resistant bacteria from animal breeding can be found in everyday consumer products [21]. Resistance to antibiotics can be very negative for the production of meat, milk, and other animal products if the prevention and treatment of bacterial infections with antibiotics becomes completely obsolete due to antibiotic resistance. Likewise, bacteria that have acquired resistance to several antibiotics could be twice as dangerous if transmission to humans is effective and especially if they are pathogenic, because the treatment of the disease induced would be more difficult [4].

\section{Residues of antibiotics in food and environment}

One of the major consequences of the use of antibiotics in agriculture and animal husbandry is the presence of residues of these substances in food and environment. Antibiotic residues are defined as all pharmacologically active substances, whether active substances, excipients, or degradation products, as well as the metabolites found in the environment or remaining in food for animals to which the drug in question has been administered [22]. These residues may pose risks to public health, in particular with the development of resistance (due to exposure of bacteria to underdoses), allergic reactions, disruption of normal flora, and potential carcinogenicity, mutagenicity, and teratogenicity [4]. With regard to the environmental risks, it is presently accepted that after an antibiotic treatment, the animals excrete in their environment a fraction of the administered dose [5]. Most certainly, there are significant disparities in the half-life time depending on the molecule: Tylosin, for example, degrades much faster than oxytetracycline, detectable in the manure of calves treated for 5 months against $<45$ days for tylosin. This signifies a long persistence of certain antibiotics in the environment, which can then be present in soil, water, and rivers, therefore leading to chemical pollution of the environment, with an action on the microbial flora which may be the same as on the commensal flora [23]. Similarly, technological risks should not be overlooked because antibiotic residues can interfere with the fermentation process during the production of certain fermented foods (cheese, yogurt, and fermented meat) by inhibiting the starter cultures [4].

\section{Use of Probiotic in Animal Breeding}

Probiotics are live microorganisms that confer health benefits on the host when administered in adequate dosage [24]. Their use in human health and farm animal production has been widely reported in the literature. Although several microorganisms, particularly bacteria and fungi, have demonstrated probiotic abilities, species belonging to the genera Lactobacillus, Streptococcus, Lactococcus, and Bifidobacterium remain the most popular probiotic

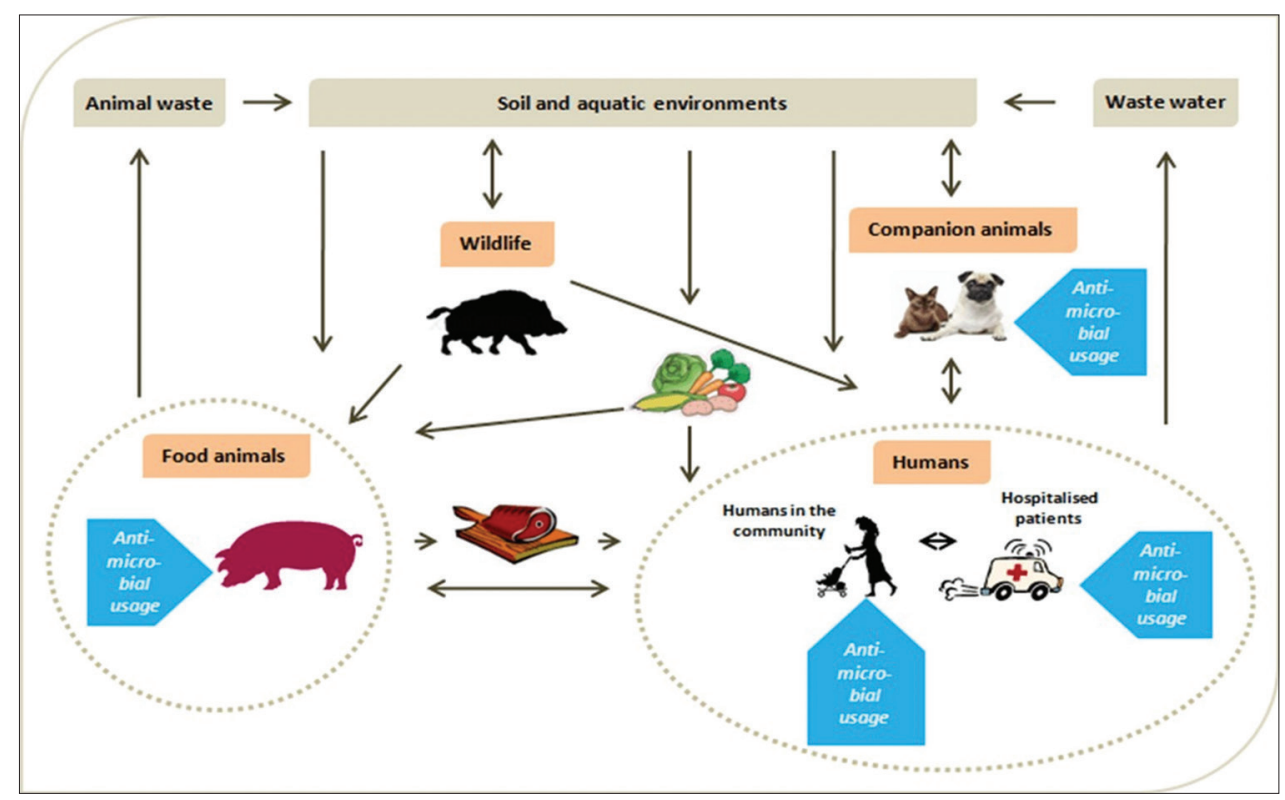

Figure-1: Exchange of resistance genes and bacteria between different reservoirs [5]. 
agents to date [25]. Very often, probiotic candidates must at least be able to modulate the immune system or certain physiological parameters of the host, attenuate virulence markers of certain pathogens, treat or prevent infectious, and inflammatory diseases and act as a biological control agent in the prevention of spoilage [26]. There are reports indicating that the use of probiotic yeast (Saccharomyces cerevisiae) and fungal strains (Aspergillus oryzae) provides better results in adult ruminants while bacterial probiotics are more effective in chickens, pigs, and young calves [26].

\section{Most used probiotics bacteria and application in animal breeding \\ Lactobacillus}

Lactobacillus is Gram-positive bacteria belonging to the group of lactic acid-producing bacteria. This group is very wide and heterogeneous and includes more than 100 different species [27]. Most of the species found in this group are part of the normal mammal's microbiota. Many species belonging to this genus are very often introduced as probiotics in both dairy and non-dairy foods intended for human consumption [24,28]. Meanwhile, some species of the genus Lactobacillus used as feed additive have demonstrated beneficial abilities, in particular, to reduce mortality in fish $[6,29]$, to improve growth performance in piglets [30], to improve production and quality of eggs in poultry [7,16,31], to improve immune defense mechanisms in fish [32], and to reduce Salmonella contamination in chicken [5-7,9-19,25,29-78] (Table-1). Otherwise, Lactobacillus strains producing active dietary enzymes including protease amylase, lipase, phytase, and protease are interesting probiotic candidates due to these enzymes' role in digestion and absorption of nutrients [79]. However, Vesterlund et al. [80] mentioned that some bacteria of this genus (such as Lactobacillus casei and Lactobacillus rhamnosus) could be involved in bacterial infections. Notwithstanding the above, most authors agree that this large group is recognized as generally safe for both animals and humans.

\section{Bifidobacterium}

Bifidobacteria are found in large numbers in the gut of animals and human. It is a very promising group as a probiotic and its presence in the gut generally indicates the good health of the host [27]. There is a general belief that this bacterium has a significant contribution in maintaining the balance of the intestinal microflora and in limiting the risk of infections. Several species are host specific [8]. Many bifidobacteria are generally used as probiotics in human food and in pharmaceutical formulations [27]. Many of these germs have "GRAS" ("Generally Regarded As Safe") status [33]. Used as a feed additive in piglets, the species Bifidobacterium pseudolongum have shown significant results on a better food conversion ratio (FCR) with no differences in final weight, weight gain, and feed intake [33]. In poultry, the species Bifidobacterium animalis, Bifidobacterium thermophilum, and Bifidobacterium longum, used as food additive have, respectively, demonstrated their ability to reduce coccidiosis in broiler chickens infected with Eimeria tenella [17,18], to have protective activity against Salmonella and Listeria species in vitro and against E. coli in chicken [34], and an anti-Campylobacter activity [35]. Overall, bacteria belonging to the Bifidobacterium genus are extensively tested for their potential application as a feed additive and as an alternative to conventional antibiotics in breeding. The results obtained are promising and their ability to specifically inhibit certain pathogens is a major asset.

\section{Bacillus}

Bacillus are Gram-positive bacteria, facultative aerobic or aero-anaerobic, heterotrophic, saprophytic, and ubiquitous. Some bacteria of this genus such as Bacillus subtilis are regularly used as a food supplement in animal breeding, especially in fish farming [36] and in poultry [37,38]. Kumar et al. [81] reported that feeding the Indian big carp Labeo rohita with $B$. subtilis at $1.5 \times 10^{7} \mathrm{CFU} / \mathrm{g}$ contributed to increased resistance against infection with $A$. hydrophila. B. subtilis, administrated at $10^{4}, 10^{6}$, and $10^{8} \mathrm{CFU} / \mathrm{g}$ for 14 and 28 days, has also demonstrated its ability to enhance the relative survival percentage of groupers, Epinephelus coioides challenged with Streptococcus spp. [39]. Several researchers agree that these species possess high potential for immunomodulation and protection against diseases in animal breeding, and recommend B. subtilis as a beneficial agent for the biological control of the diseases [25]. Otherwise, other species of the genus Bacillus like Bacillus licheniformis have also shown probiotic aptitudes, when used as a feed additive in pigs, and have shown to be effective against diarrhea occurring in piglets in 3-10 days post weaning caused by enterotoxic strains of E. coli [19]. Although some species like Bacillus cereus can cause problems due to the endotoxins and emetic toxins they produce [82], bacteria of the genus Bacillus already used as probiotics have real potential and can be used in safe production and as an alternative to conventional antibiotics.

\section{Enterococcus}

Enterococcus is a common member of the endogenous intestinal microbiota of humans and animals [83]. Although this genus is not considered "generally recognized as safe", species from the genus Enterococcus have been used as probiotic for human or animals $[83,84]$. Enterococcus strains have been used as feed additives in poultry and swine as alternatives to the use of sub-lethal antibiotics in the feeds. Several studies aimed to evaluate the probiotic aptitudes of species of the genus Enterococcus have been carried out, and most of these studies focused on Enterococcus faecium. In a study conducted by 


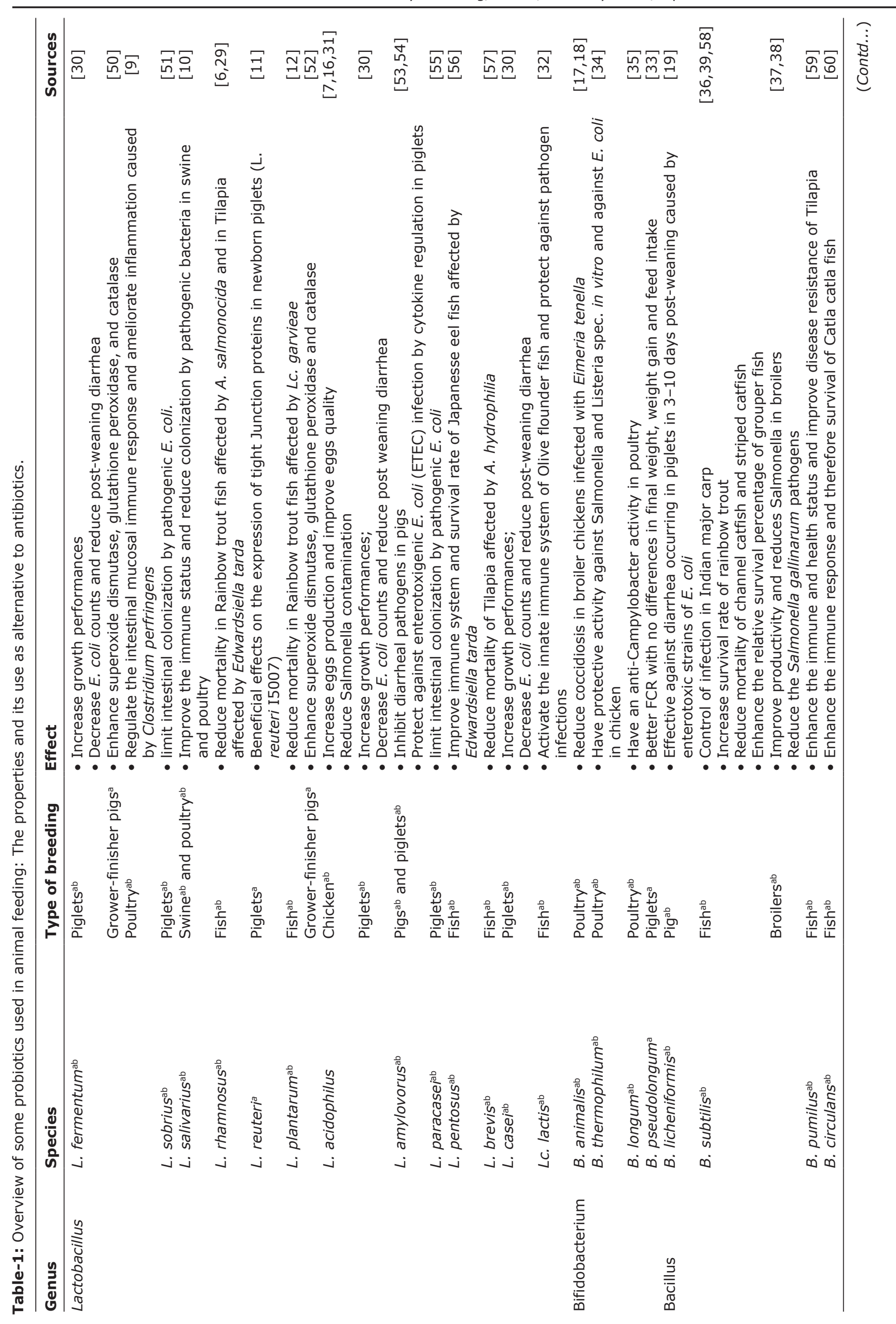




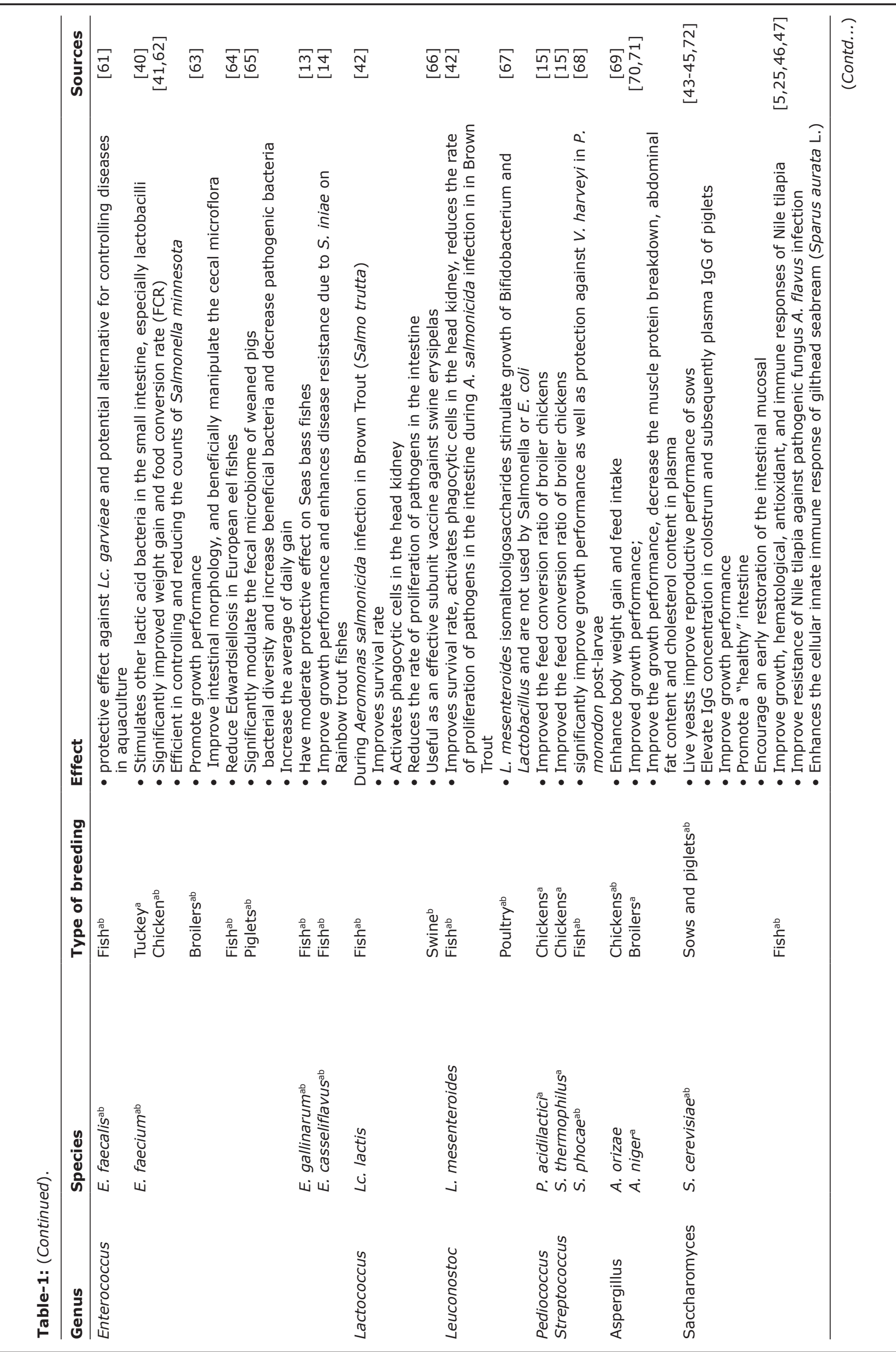




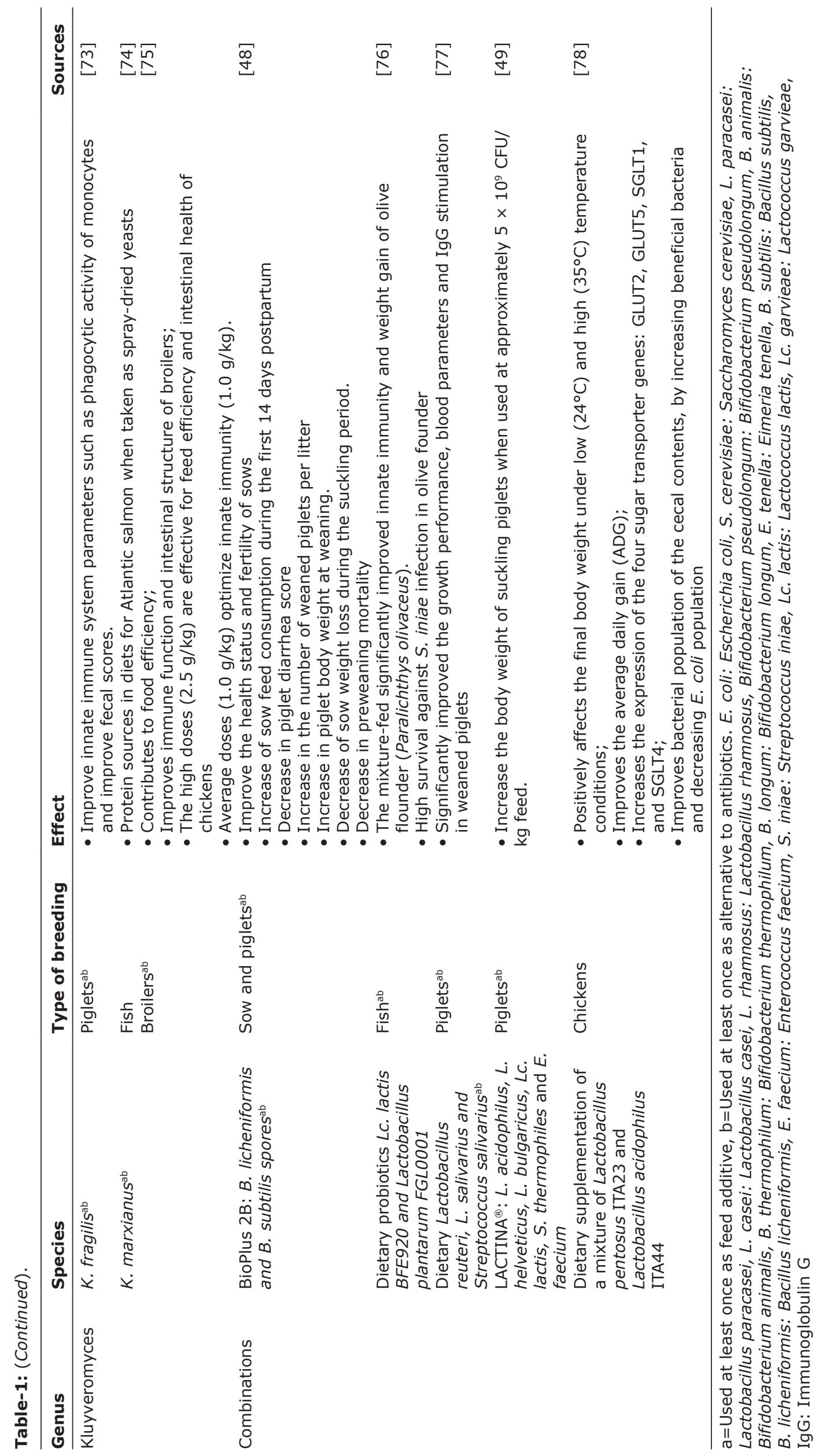


Pollmann et al. [85] to investigate the impact of probiotic additives on the rate of endogenous Chlamydia infection in pigs, a microencapsulated $E$. faecium SF68 (NCIMB 10415), containing $9 \times 10^{9} \mathrm{CF} / \mathrm{g}$ bacteria has shown positive results and a reduction in the severity of infections as well as the number of infections caused by Chlamydiae. The strain E. faecium has also demonstrated its ability to stimulate other lactic acid bacteria (especially Lactobacillus) in the small intestine of a turkey [40], improve the FCR in chicken [41], improve intestinal morphology, and beneficially manipulate the cecal microflora in broilers [9] (Table-1). Some other beneficial effects of E. faecium and other strains of the Enterococcus genus on poultry, pigs, and fish are listed in Table-1. However, the Enterococcus genus does not only have advantages, as these bacteria may participate in transmission of resistance to antibiotics [82]. Moreover, this genus is often associated with pathogenesis such as infections of the urogenital tract [86] and endocarditis [87]. Sometimes, these strains are involved in the production of substances such as $\beta$-hemolysin, gelatinase, and aggregation substance that are undesirable phenotypes in probiotic strains [83]. Despite having demonstrated good results in animal breeding, the use of probiotics belonging to this genus must be checked beforehand to use only strains which do not present any danger to the health of the animal.

\section{Lactococcus}

Lactococcus strains are commonly used in the manufacture of fermented dairy products. Some of them have been tested for probiotic properties, especially in fish and the results have proven to be satisfactory and promising [42]. Special interest is placed on the study of Lactococcus lactis and this species was capable of protecting different fish species against bacterial pathogens [25]. In a study conducted by Balcázar et al. [42], Lc. lactis administered to brown trout as a feed additive revealed its ability to increase immune parameters as well as protect against furunculosis. In the same vein, Heo et al. [88] reported the use of Lc. Lactis $\left(10^{8} \mathrm{CFU} / \mathrm{g}\right)$ in olive flounder elevated serum immune parameters (such as serum peroxidase, lysozyme, antiprotease, and blood respiratory burst activities) as well as resistance against Streptococcus iniae. Although Lc. lactis is considered safe for human and animal use, some studies have also linked Lactococcus bacteria (Lc. lactis and Lactococcus garvieae) to infection [89]. It is, therefore, necessary to regularly carry out trials before implementing the strains of this genus in animal feed, either as an additive or as a means of disease control.

\section{Saccharomyces}

Saccharomyces is a genus of budding yeast; it is also part of the gut microbiota. In this fungal genus, $S$. cerevisiae is the best-known specie and most used as a probiotic. $S$. cerevisiae has been recognized to improve reproductive performance of sows elevate immunoglobulin $\mathrm{G}(\mathrm{IgG})$ concentration in colostrum and subsequently plasma IgG of piglets, to improve growth performance and promote "healthy" intestines of pigs [43-45]. Positive results of the use of $S$. cerevisiae have also been observed in fish. S. cerevisiae has been shown to be able to improve growth, hematological, antioxidant, and immune responses of Nile tilapia, improve resistance of Nile tilapia against pathogenic fungus $A$. flavus infection as well as enhance the cellular innate immune response of gilthead seabream $[25,46,47,90]$. Other species belonging to this genus such as Saccharomyces carlsbergensis are also used as probiotics in animal feeding [27].

\section{Other probiotics and combinations of probiotics}

Certain other strains used as probiotics in animal feed as well as their positive effect on the host are given in Table-1. Furthermore, although the benefits of using a combination of more than one probiotic in the same food formulation are not yet demonstrated, most commercial products such as BioPlus 2B [48] and LACTINA ${ }^{\circledR}$ [49] contain various probiotic strains (Table-1)

\section{Conclusion}

The beneficial properties of probiotics when used as a feed additive are very encouraging for animal breeding. The study of the existing literature on this subject allowed us to highlight their potential use as an alternative for conventional antibiotics. However, more research should be done to standardize the use of specific probiotic strains in the breeding of specific animals, while maintaining the properties already demonstrated.

\section{Authors' Contributions}

MMJA, AKLD, and RM conceptualized and designed review, literature search, and wrote the first manuscript draft. SLA, EAV, BZC, and IK edited and revised the final draft of the review article. All authors critically reviewed the manuscript and gave final approval of the version to be published.

\section{Acknowledgment}

This publication was supported by the Ministry of Education and Science of the Russian Federation on the program to improve the competitiveness of RUDN University program 5-100 among the world leading research and education centers in 2016-2020 and Topic No. 031620-0-000.

\section{Competing Interests}

The authors declare that they have no competing interests.

\section{Publisher's Note}

Veterinary World remains neutral with regard to jurisdictional claims in published institutional affiliation. 


\section{References}

1. Camilleri, G.M., Verger, E.O., Huneau, J.F., Carpentier, F., Dubuisson, C. and Mariotti, F. (2013) Plant and animal protein intakes are differently associated with nutrient adequacy of the diet of French adults. J. Nutr., 143(9): 1466-1473.

2. Food and Agriculture Organization. (2009) Forum D'experts de Haut Niveau L'agriculture Mondiale à l'horizon 2050, 12-13 Octobre. Food and Agriculture Organization, Rome, Italy.

3. Mottet, A., de Haan, C., Falcucci, A., Tempio, G., Opio, C. and Gerber, P. (2017) Livestock: On our plates or eating at our table? A new analysis of the feed/food debate. Glob. Food Secur., 14: 1-18.

4. Beyene, T. (2016) Veterinary drug residues in food-animal products: Its risk factors and potential effects on public health. J. Vet. Sci. Technol., 7(1): 1-7.

5. AMCRA. (2020) Centre de Connaissances Concernant L'utilisation des Antibiotiques et L'antibiorésistance Chez les Animaux. Available from: https:/www.amcra.be/fr/antibiotiques-et-antibioresistance..Retrieved on 13/09/2020.

6. Nikoskelainen, S., Ouwehand, A.C., Bylund, G., Salminen, S. and Lilius, E.M. (2003) Immune enhancement in rainbow trout (Oncorhynchus mykiss) by potential probiotic bacteria (Lactobacillus rhamnosus). Fish Shellfish Immunol., 15(5): 443-452.

7. Kurtoglu, V., Kurtoglu, F., Seker, E., Coskun, B., Balevi, T. and Polat, E.S. (2004) Effect of probiotic supplementation on laying hen diets on yield performance and serum and egg yolk cholesterol. Food Addit. Contam., 21(9): 817-823.

8. Biavati, B. and Mattarelli, P. (2018) Related genera within the family Bifidobacteriaceae. In: The Bifidobacteria and Related Organisms. Academic Press, Cambridge. p49-66.

9. Cao, L., Yang, X.J., Li, Z.J., Sun, F.F., Wu, X.H. and Yao, J.H. (2012) Reduced lesions in chickens with Clostridium perfringens-induced necrotic enteritis by Lactobacillus fermentum 1.20291. Poult. Sci., 91(12): 3065-3071.

10. Chaves, B.D., Brashears, M.M. and Nightingale, K.K. (2017) Applications and safety considerations of Lactobacillus salivarius as a probiotic in animal and human health. J. Appl. Microbiol., 123(1): 18-28.

11. Yang, F., Wang, A., Zeng, X., Hou, C., Liu, H.S. and Qiao, S. (2015) Lactobacillus reuteri 15007 modulates tight junction protein expression in IPEC-J2 cells with LPS stimulation and in newborn piglets under normal conditions. BMC Microbiol., 15(35): 32 .

12. Vendrell, D., Balcazar, J.L., Blas, I.D., Ruiz-Zzarzuela, I., Girones, O. and Muzquiz, J.L. (2008) Protection of rainbow trout (Oncorhynchus mykiss) from lactococcosis by probiotic bacteria. Comp. Immunol. Microb., 31(4): 337-345.

13. Sorroza, L., Real, F., Acosta, F., Acosta, B., Deniz, S., Roman, L., El Aamri, F. and Padilla, D. (2013) A probiotic potential of Enterococcus gallinarum against Vibrio anguillarum infection. Fish Pathol., 48(1): 9-12.

14. Safari, R., Adel, M., Lazado, C.C., Caipang, C.M. and Dadar, M. (2016) Host-derived probiotics Enterococcus casseliflavus improves resistance against Streptococcus iniae infection in rainbow trout (Oncorhynchus mykiss) via immunomodulation. Fish Shellfish Immunol., 52: 198-205.

15. Harimurti, S. and Hadisaputro, W. (2015) Probiotics in poultry. In: Beneficial Microorganisms in Agriculture, Aquaculture and Other Areas. Springer, Cham. p1-19.

16. Van Immerseel, F., Russell, J.B., Flythe, M.D., Gantois, I., Timbermont, L., Pasmans, F. and Haesebrouck, F. (2006) The use of organic acids to combat Salmonella in poultry: A mechanistic explanation of the efficacy. Avian Pathol., 35(3): 182-188.

17. Giannenas, I., Papadopoulos, E., Tsalie, E., Triantafillou, E., Henikl, S., Teichmann, K. and Tontis, D. (2012) Assessment of dietary supplementation with probiotics on performance, intestinal morphology and microflora of chickens infected with Eimeria tenella. Vet. Parasitol., 188(1-2): 31-40.

18. Jungersen, M., Wind, A., Johansen, E., Christensen, J., Stuer-Lauridsen, B. and Eskesen, D. (2014) The science behind the probiotic strain Bifidobacterium animalis subsp. lactis BB-12 ${ }^{\circledR}$. Microorganisms, 2(2): 92-110.

19. Kyriakis, S.C., Tsiloyiannis, V.K., Vlemmas, J., Sarris, K., Tsinas, A.C., Alexopoulos, C. and L. Jansegers. (1999) The effect of probiotic LSP 122 on the control of post-weaning diarrhea syndrome of piglets. Res. Vet. Sci., 67(3): 223-228.

20. Acar, J. and Röstel, B. (2001) Antimicrobial resistance: An overview. Rev. Sci. Tech. OIE, 20(3): 797-810.

21. Mbarga, M.J.A., Andreevna, S.L. and Viktorovna, P.I. (2020) Evaluation of apparent microflora and study of antibiotic resistance of coli forms isolated from the shells of poultry eggs in Moscow-Russia. $J$. Adv. Microbiol., 20(4): 70-77.

22. Kölbener, P. (2005) Résidus de Médicaments Vétérinaires. Manuel Suisse des Denrées Alimentaires. Ch. 55. p1-2 www.baganw.admin.ch/SLMB Online PDF/Data $\% 20$ SLMB_MSDA/Version $\% 20 \mathrm{~F} / 55$ _Resi dus $\% 20 \mathrm{de} \% 20$ medi.\%20veter..pdf. Retrieved on 10/07/2020.

23. Chatellet, M.C. (2007) Modalités D'utilisation des Antibiotiques en Elevage Bovin: Enquête en Anjou. Thesis of Veterinary Doctor, National Veterinary School of ALFORT.

24. Hammes, W. P. and Hertel, C (2006) The genera Lactobacillus and Carnobacterium, p320-403, The Prokaryotes, 3rd edition, vol. 4, ed. by Dworkin, M., Falkow, S., Rosenberg, E., Schleifer K.-H. and Stackebrandt, E., Springer, New York.

25. Hoseinifar, S.H., Sun, Y.Z., Wang, A. and Zhou, Z. (2018) Probiotics as means of disease control in aquaculture, a review of current knowledge and future perspectives. Front. Microbiol., 9: 2429.

26. Markowiak, P. and Śliżewska, K. (2018) The role of probiotics, prebiotics and synbiotics in animal nutrition. Gut Pathog., 10(1): 21.

27. Gaggia, F., Mattarelli, P. and Biavati, B. (2010) Probiotics and prebiotics in animal feeding for safe food production. Int. J. Food Microbiol., 141(Suppl 1): S15-S28.

28. Mbarga, M.J.A., Zangué, S.C.D., Tatsadjieu, L.N., Zargar, M., Albert, E. and Bayat, M. (2019) Producing probiotic beverage based on raffia sap fermented by Lactobacillus fermentum and Bifidobacterium bifidum. Res. Crops, 20(3): 629-634.

29. Pirarat, N., Kobayashi, T., Katagiri, T., Maita, M. and Endo, M. (2006) Protective effects and mechanisms of a probiotic bacterium Lactobacillus rhamnosus against experimental Edwardsiella tarda infection in tilapia (Oreochromis niloticus). Vet. Immunol. Immunopathol., 113(3-4): 339-347.

30. Huang, C.H., Qiao, S.Y., Li, D.F., Piao, X.S. and Ren, J.P. (2004) Effects of lactobacilli on the performance diarrhea incidence VFA concentration and gastrointestinal microbial flora of weaning pigs. Asian Aust. J. Anim. Sci., 17(3): 401-409.

31. Haddadin, M.S.Y., Abdulrahim, S.M. and Hashlamoun, E.A. and Robinson, R.K. (1996) The effects of Lactobacillus acidophilus on the production and chemical composition of hen's eggs. Poult. Sci., 75(4): 491-494.

32. Kim, D., Beck, B.R., Heo, S.B., Kim, J., Kim, H.B., Lee, S.M., Kim, Y., Oh, S.Y., Lee, K., Do, H.K., Lee, K.H., Holzapfel, W.H. and Song, S.K. (2013) Lactococcus lactis BFE920 activates the innate immune system of olive flounder (Paralichthys olivaceus), resulting in protection against Streptococcus iniae infection and enhancing feed effciency and weight gain in large scale field-studies. Fish Shellfish Immunol., 35(5): 1585-1590.

33. Afonso, E.R., Parazzi, L.J., Marino, C.T., Martins, S.M.M., Araújo, L.F., Araújo, C.S.D. and Moretti, A.D.S. (2013) Probiotics association in the suckling and nursery in piglets challenged with Salmonella Typhimurium. Braz. Arch. Biol. Technol., 56(2): 249-258. 
34. Tanner, S.A., Chassard, C., Rigozzi, E., Lacroix, C. and Stevens, M.J.A. (2016) Bifidobacterium thermophilum RBL67 impacts on growth and virulence gene expression of Salmonella enterica subsp. enterica serovar Typhimurium. BMC Microbiol., 16(1): 46.

35. Santini, C., Baffoni, L., Gaggia, F., Granata, M., Gasbarri, R., Di Gioia, D. and Biavati, B. (2010) Characterization of probiotic strains: An application as feed additives in poultry against Campylobacter jejuni. Int. J. Food Microbiol., 141(Suppl 1): S98-S108.

36. Newaj-Fyzul, A., Adesiyun, A.A., Mutani, A., Ramsubhag, A., Brunt, J. and Austin, B. (2007) Bacillus subtilis $\mathrm{AB} 1$ controls Aeromonas infection in rainbow trout (Oncorhynchus mykiss, Walbaum). J. Appl. Microbiol., 103(5): 1699-1706.

37. Park, J.H. and Kim, I.H. (2014) Supplemental effect of probiotic Bacillus subtilis B2A on productivity, organ weight, intestinal Salmonella microflora, and breast meat quality of growing broiler chicks. Poult. Sci., 93(8): 2054-2059.

38. Upadhaya, S.D., Hossiendoust, A. and Kim, I.H. (2016) Probiotics in Salmonella-challenged Hy-Line brown layers. Poult. Sci., 95(8): 1894-1897.

39. Liu, C.H., Chiu, C.H., Wang, S.W. and Cheng, W. (2012) Dietary administration of the probiotic, Bacillus subtilis E20, enhances the growth, innate immune responses, and disease resistance of the grouper, Epinephelus coioides. Fish Shellfish Immunol., 33(4): 699-706.

40. Vahjen, W., Jadamus, A. and Simon, O. (2002) Influence of a probiotic Enterococcus faecium strain on selected bacterial groups in the small intestine of growing Turkey poults. Arch. Anim. Nutr., 56(6): 419-429.

41. Samli, H.E., Senkoylu, N., Koc, F., Kanter, M. and Agma, A. (2007) Effects of Enterococcus faecium and dried whey on broiler performance, gut histomorphology and intestinal microbiota. Arch. Anim. Nutr., 61(1): 42-49.

42. Balcázar, J.L., Vendrell, D., De Blas, I., Ruiz-Zarzuela, I. and Múzquiz, J.L. (2009) Effect of Lactococcus lactis CLFP 100 and Leuconostoc mesenteroides CLFP 196 on Aeromonas salmonicida infection in brown trout (Salmo trutta). J. Mol. Microbiol. Biotechnol., 17(3): 153-157.

43. LeMieux, F.M., Naranjo, V.D., Bidner, T.D. and Southern,L.L. (2010) Effect of dried brewers yeast on growth performance of nursing and weanling pigs. Prof. Anim. Sci., 26(1): 70-75.

44. Bontempo, V., Di Giancamillo, A., Savoini, G., Dell'Orto, V. and Domeneghini, C. (2006) Live yeast dietary supplementation acts upon intestinal morpho-functional aspects and growth in weanling piglets. Anim. Feed Sci. Technol., 129(3-4): 224-236.

45. Heugten, E.V., Funderburke, D.W. and Dorton, K.L. (2003) Growth performance, nutrient digestibility, and fecal microflora in weanling pigs fed live yeast. J. Anim. Sci., 81(4): 1004-1012.

46. Abdel-Tawwab, M., Adeshina, I. and Issa, Z.A. (2020) Antioxidants and immune responses, resistance to Aspergilus flavus infection, and growth performance of Nile tilapia, Oreochromis niloticus, fed diets supplemented with yeast, Saccharomyces cerevisiae. Anim. Feed Sci. Technol., 2020(263): 114484.

47. Ortuño, J., Cuesta, A., Rodríguez, A., Esteban, M.A. and Meseguer, J. (2002) Oral administration of yeast, Saccharomyces cerevisiae, enhances the cellular innate immune response of gilthead seabream (Sparus aurata L.). Vet. Immunol. Immunopathol., 85(1-2): 41-50.

48. Alexopoulos, C., Georgoulakis, I.E., Tzivara, A., Kritas, S.K., Siochu, A. and Kyriakis, S.C. (2004) Field evaluation of the efficacy of a probiotic containing Bacillus licheniformis and Bacillus subtilis spores, on the health status and performance of sows and their litters. J. Anim. Physiol. Anim. Nutr., 88(11-12): 381-392.

49. EFSA Panel on Additives and Products or Substances Used in Animal Feed. (2013) Scientific opinion on the safety and efficacy of probiotic LACTINA ${ }^{\circledR}$ (Lactobacillus acidophilus, Lactobacillus helveticus, Lactobacillus bulgaricus, Lactobacillus lactis, Streptococcus thermophilus and Enterococcus faecium) for chickens for fattening and piglets. EFSA J., 11(4): 3170.

50. Wang, A., Yu, H., Gao, X., Li, X. and Qiao, S. (2009) Influence of Lactobacillus fermentum I5007 on the intestinal and systemic immune responses of healthy and $E$. coli challenged piglets. Antoine Van Leeuwenhoek, 96(1): 89-98.

51. Konstantinov, S.R., Smidt, H., Akkermans, A.D.L., Casini, L., Trevisi, P., Mazzoni, M., De Filippi, S., Bosi, P. and de Vos, W. (2008) Feeding of Lactobacillus sobrius reduces Escherichia coli $\mathrm{F} 4$ levels in the gut and promotes growth of infected piglets. FEMS Microbiol. Ecol., 66(3): 599-607.

52. Wang, J., Ji, H.F., Wang, S.X., Zhang, D.Y., Liu, H., Shan, D.C. and Wang, Y.M. (2012) Lactobacillus plantarum ZLP001: In vitro assessment of antioxidant capacity and effect on growth performance and antioxidant status in weaning piglets. Asian Australas. J. Anim. Sci., 25(8): 1153-1158.

53. Finamore, A., Roselli, M., Imbinto, A., Seeboth, J., Oswald, I.P. and Mengheri, E. (2014) Lactobacillus amylovorus inhibits the TLR4 inflammatory signaling triggered by enterotoxigenic Escherichia coli via modulation of the negative regulators and involvement of TLR2 in intestinal Caco-2 cells and pig explants. PLoS One, 9(4): e94891.

54. Bajagai, Y.S., Klieve, A.V., Dart, P.J., Bryden, W.L. and Food and Agriculture Organization. (2016) In: Makkar, H.P.S., editor. Probiotics in Animal Nutrition Production, Impact and Regulation. FAO Animal Production and Health, Paper No. 179, Rome.

55. Bomba, A., Nemcova, R., Gancarcikova, S., Herich, R., Guba, P. and Mudronova, D. (2002) Improvement of the probiotic effect of microorganisms by their combination with maltodextrins, fructo-oligosaccharides and polyunsaturated fatty acids. Br. J. Nutr., 88(1): 95-99.

56. Lee, J.S., Cheng, H., Damte, D., Lee, S.J., Kim, J.C., Rhee, M.H., Suh, J.W. and Park, S.C. (2013) Effects of dietary supplementation of Lactobacillus pentosus PL11 on the growth performance, immune and antioxidant systems of Japanese eel Anguilla japonica challenged with Edwardsiella tarda. Fish Shellfish Immunnol., 34(3): 756-761.

57. Liu, W., Ren, P., He, S., Xu, L., Yang, Y., Gu, Z. and Zhou, Z. (2013) Comparison of adhesive gut bacteria composition, immunity, and disease resistance in juvenile hybrid tilapia fed two different Lactobacillus strains. Fish Shellfish Immunol., 35(1): 54-62.

58. Ran, C., Carrias, A., Williams, M.A., Capps, N. and Dan, B.C.T. (2012) Identification of Bacillus strains for biological control of catfish pathogens. PLoS One, 7(9): e45793.

59. Aly, S.M., Ahmed, Y.A.G., Ghareeb, A.A.A. and Mohamed, M.F. (2008) Studies on Bacillus subtilis and Lactobacillus acidophilus, as potential probiotics, on the immune response and resistance of Tilapia nilotica (Oreochromis niloticus) to challenge infections. Fish Shellfish Immunol., 25(1-2): 128-136.

60. Bandyopadhyay, P. and Das Mohapatra, P.K. (2009) Effect of a probiotic bacterium Bacillus circulans $\mathrm{PB} 7$ in the formulated diets: On growth, nutritional quality and immunity of Catla catla (Ham.). Fish Physiol. Biochem., 35(3): 467-478.

61. Baños, A., Ariza, J.J., Nuñez, C., Gil-Martínez, L., GarcíaLópez, J.D., Martínez-Bueno, M. and Valdivia, E. (2019) Effects of Enterococcus faecalis UGRA10 and the enterocin AS-48 against the fish pathogen Lactococcus garvieae. Studies in vitro and in vivo. Food Microbiol., 77: 69-77.

62. Kuritza, L.N., Pickler, L., Miglino, L.B., Westphal, P., 
Lourenço, M.C., Toledo, M. and Muniz, E.C. (2011) Probióticos a Base de Enterococcus faecium NCIMB 10415 no Controle da Salmonella Minnesota em Frangos de Corte. In: $22^{\text {nd }}$ Congresso Latino Americano de Aves, Buenos Aires, Argentina.

63. Cao, G.T., Zeng, X.F., Chen, A.G., Zhou, L., Zhang, L., Xiao, Y.P. and Yang, C.M. (2013) Effects of a probiotic, Enterococcus faecium, on growth performance, intestinal morphology, immune response, and cecal microflora in broiler chickens challenged with Escherichia coli K88. Poult. Sci., 92(11): 2949-2955.

64. Chang, C.I. and Liu, W.Y. (2002) An evaluation of two probiotic bacterial strains, Enterococcus faecium SF68 and Bacillus toyoi, for reducing edwardsiellosis in cultured European eel (Anguilla anguilla). J. Fish. Dis., 25(5): 311-315.

65. Pajarillo, E.A.B., Chae, J.P., Balolong, M.P., Kim, H.B., Park, C.S. and Kang, D.K. (2015) Effects of probiotic Enterococcus faecium NCIMB 11181 administration on swine fecal microbiota diversity and composition using barcoded pyrosequencing. Anim. Feed Sci. Technol., 201: 80-88.

66. Cheun, H.I., Kawamoto, K., Hiramatsu, M., Tamaoki, H., Shirahata, T., Igimi, S. and Makino, S.I. (2004) Protective immunity of SpaA-antigen producing Lactococcus lactis against Erysipelothrix rhusiopathiae infection. J. Appl. Microbiol., 96(6): 1347-1353.

67. Chung, C.H. and Day, D.F. (2004) Efficacy of Leuconostoc mesenteroides (ATCC 13146) isomaltooligosaccharides as a poultry prebiotic. Poult. Sci., 83(8): 1302-1306.

68. Swain, S.M., Singh, C. and Arul, V. (2009) Inhibitory activity of probiotics Streptococcus phocae PI80 and Enterococcus faecium MC13 against vibriosis in shrimp Penaeus monodon. World J. Microbiol. Biotechnol., 25(4): 697-703.

69. Kim, S.H., Park, S.Y., Yu, D.J., Lee, S.J., Ryu, K.S. and Lee, D.G. (2003) Effects of feeding Aspergillus oryzae ferments on performance, intestinal microflora, blood serum components and environmental factors in broiler. Korea $J$. Poult. Sci., 30(3): 151-159.

70. Saleh, A.A., Eid, Y.Z., Ebeid, T.A., Kamizono, T., Ohtsuka, A. and Hayashi, K. (2011) Effects of feeding Aspergillus awamori and Aspergillus niger on growth performance and meat quality in broiler chickens. J. Poult. Sci., 48(3): 201-206.

71. Saleh, A.A., Eid, Y.Z., Ebeid, T.A., Amber, K., Badawi, N. and Hayashi, K. (2010) Effect of Aspergillus niger on broilers performance. Egypt. Poult. Sci. J., 30(4): 1017-1029.

72. Jang, Y.D., Kang, K.W., Piao, L.G., Jeong, T.S., Auclair, E., Jonvel, S., D'Inca, R. and Kim, Y.Y. (2013) Effects of live yeast supplementation to gestation and lactation diets on reproductive performance, immunological parameters and milk composition in sows. Livest. Sci., 152(2-3): 167-173.

73. Keimer, B., Pieper, R., Simon, A. and Zentek, J. (2018) Effect of time and dietary supplementation with processed yeasts (Kluyveromyces fragilis) on immunological parameters in weaned piglets. Anim. Feed Sci. Technol., 245(1): 136-146.

74. Øverland, M., Karlsson,A., Mydland, L.T., Romarheim, O.H. and Skrede, A. (2013) Evaluation of Candida utilis, Kluyveromyces marxianus and Saccharomyces cerevisiae yeasts as protein sources in diets for Atlantic salmon (Salmo salar). Aquaculture, 402: 1-7.

75. Wang, W., Li, Z., Lv, Z., Zhang, B., Lv, H. and Guo, Y. (2017) Effects of Kluyveromyces marxianus supplementation on immune responses, intestinal structure and microbiota in broiler chickens. PLoS One, 12(7): e0180884.

76. Beck, B.R., Kim, D., Jeon, J., Lee, S.M., Kim, H.K., Kim, O.J., Lee, J.I., Suh, B.S., Do, H.K., Lee, K.H.,
Holzapfel, W.H., Hwang, J.Y., Kwon, M.G. and Song, S.K. (2015) The effects of combined dietary probiotics Lactococcus lactis BFE920 and Lactobacillus plantarum FGL0001 on innate immunity and disease resistance in olive flounder (Paralichthys olivaceus). Fish Shellfish Immunol., 42(1): 177-183.

77. Dlamini, Z.C., Langa, R.L.S., Aiyegoro, O.A. and Okoh, A.I. (2017) Effects of probiotics on growth performance, blood parameters, and antibody stimulation in piglets. S. Afr. J. Anim. Sci., 47(6): 765-776..

78. Jahromi, M.F., Altaher, Y.W., Shokryazdan, P., Ebrahimi, R., Ebrahimi, M., Idrus, Z., Tufarelli, V. and Liang, J.B. (2016) Dietary supplementation of a mixture of Lactobacillus strains enhances performance of broiler chickens raised under heat stress conditions. Int. J. Biometeorol., 60(7): 1099-1110.

79. Kim, E.Y., Kim, Y.H., Rhee, M.H., Song, J.C., Lee, K.W., Kim, K.S., Lee, S.P, Lee, I.S. and Park, S.C. (2007) Selection of Lactobacillus spp. PSC101 that produces active dietary enzymes such as amylase, lipase, phytase and protease in pigs. J. Gen. Appl. Microbiol., 53(2): 111-117.

80. Vesterlund, S., Vankerckhoven, V., Saxelin, M., Goossens, H., Salminen, S. and Ouwehand, A.C. (2007) Safety assessment of Lactobacillus strains: Presence of putative risk factors in faecal, blood and probiotic isolates. Int. J. Food Microbiol., 116(3): 325-331.

81. Kumar, R., Mukherjee, S.C., Prasad, K.P. and Pal, A.K. (2006) Evaluation of Bacillus subtilis as a probiotic to Indian major carp, Labeo rohita (Ham). Aquac. Res., 37(12): 1215-1221.

82. Anadón, A., Martínez-Larrańaga, M.R. and Martínez, M.A. (2006) Probiotics for animal nutrition in the European Union, regulation and safety assessment. Regul. Toxicol. Pharmacol., 45(1): 91-95.

83. Araújo, T.F. and Célia, L.L.F. (2013) The genus Enterococcus as probiotic: Safety concerns. Braz. Arch. Biol. Technol., 56(3): 457-466.

84. Sivieri, K., Spinardi-Barbisan, A.L.T., Barbisan, L.F., Bedani, R., Pauly, N.D. and Carlos, I.Z., Benzatti, F., Vendramini, R.C. and Rossi, E.A. (2008) Probiotic Enterococcus faecium CRL 183 inhibit chemically induced colon cancer in male Wistar rats. Eur. Food Res. Technol., 228(2): 231-237

85. Pollmann, M., Nordhoff, M., Pospischil, A., Tedin, K. and Wieler, L.H. (2005) Effects of a probiotic strain of Enterococcus faecium on the rate of natural chlamydia infection in swine. Infect. Immun., 74(7): 4346-4353.

86. Protonotariou, E., Dimitroulia, E., Pournaras, S., Pitiriga, V., Sofianou, D. and Tsakris, A. (2010) Trends in antimicrobial resistence of clinical isolates of Enterococcus faecalis and Enterococcus faecium in Greece between 2002 and 2007. J. Hosp. Infect., 75(3): 225-227.

87. Heikens, E., Bonten, M.J.M. and Willems, R.J.L. (2007) Enterococcal surface protein Esp is important for biofilm formation of Enterococcus faecium E1162. J. Bacteriol., 189(22): 8233-8240.

88. Heo, W.S., Kim, Y.R., Eun-Young, K., Bai, S.C. and Kong, I.S. (2013) Effects of dietary probiotic, Lactococcus lactis subsp. lactis I2, supplementation on the growth and immune response of olive flounder (Paralichthys olivaceus). Aquaculture, 376-376: 20-24.

89. Rodrigues, M.X., Lima, S.F., Higgins, C.H., CanniattiBrazaca, S.G. and Bicalho, R.C. (2016) The Lactococcus genus as a potential emerging mastitis pathogen group: A report on an outbreak investigation. J. Dairy Sci., 99(12): 9864-9874.

90. Hai, N.V. (2015) Research findings from the use of probiotics in tilapia aquaculture: A review. Fish Shellfish Immunol., 45(2): 592-597. 